ECCOMAS

Proceedia Computational Methods in Structural Dynamics and Earthquake Engineering

M. Papadrakakis, M. Fragiadakis (eds.) Streamed from Athens, Greece, 28 - 30 June 2021

\title{
NON-DESTRUCTIVE AND DESTRUCTIVE TESTS ON OPUS INCERTUM MASONRY PANELS
}

\author{
F. $_{\text {Autiero }}{ }^{*}$, G. De Martino ${ }^{1}$, M. Di Ludovico ${ }^{1}$, A. Prota $^{1}$ \\ ${ }^{1}$ Department of Structures for Engineering and Architecture, University of Naples Federico II, Italy \\ e-mail: francesca.autiero@unina.it \\ giuseppina.demartino2@unina.it \\ diludovi@unina.it \\ aprota@unina.it
}

\begin{abstract}
The conservation of ancient masonry structures requires knowledge of their structural behavior. At the same time, the possibility to perform standard mechanical tests on heritage structures is limited by the need for the preservation of the cultural heritage.

This paper presents the results of a deep experimental program aimed at the mechanical characterization of masonry panels reproducing the ancient technique opus incertum found at the Pompeii archaeological site. They were built based on the traditional technique by using original rock units and a typical mortar mixture. The experimental program firstly involved sonic pulse velocity tests and diagonal compression tests on three masonry panels, $1.20 \mathrm{~m} \times 1.20 \mathrm{~m} \times 0.45 \mathrm{~m}$. Then, axial compression tests on five masonry specimens extracted from the three panels were carried out.

In the following, the main results of the experimental program are presented and discussed and relevant correlations among the results of non-destructive tests and destructive tests are defined to provide a useful tool for a preliminary assessment of the structural behavior of similar ancient masonries.

\section{Keywords}

Pompeii archaeological site; Masonry Panels, Rubble Stone Masonry, Non-destructive tests, Axial Compression Test, Mechanical Properties
\end{abstract}




\section{INTRODUCTION}

The conservation of heritage masonry structures set specific issues from a structural point of view concerning the achievement of adequate knowledge of the mechanical parameters of the structural elements and their components [1,2]. Despite different methodologies are available for the investigation of the mechanical properties of existing building materials and masonry assemblages, several limitations may occur in heritage contexts. Indeed, the execution of destructive and minordestructive tests, DTs and MDTs (e.g. diagonal compression tests, axial compression tests, single or double flat-jack tests), which is required for a direct estimation of fundamental mechanical parameters, is strongly restricted in such a context. This is related to the need for conservation of the heritage structures and technical challenges related to the extraction of undamaged and adequate size test specimens. On the other hand, non-destructive tests, NDTs (e.g. sonic tests, tomography, radar, thermography), can provide only a qualitative evaluation of structures (i.e. homogeneity and consistency of the specimens, presence of voids or material alterations) or indirect estimation of the mechanical parameters based on empirical correlations with DTs results. Moreover, their results are strongly affected by the structural state of conservation and by test conditions. For these reasons, the implementation of appropriate databases containing the results of different types of tests related to specific material and structural typologies can be very useful tools for the definition, by analogy, of the mechanical properties of similar elements.

A possible approach for the structural knowledge of heritage masonry structures is the realization and testing of new masonry panels representing the old typologies. This would allow performing a comprehensive experimental program involving the execution of DTs to obtain essential information on the structural behavior of traditional masonry typologies. Moreover, the execution of NDTs on reproduced panels would allow a comparison with the results obtained on the ancient structures. Stone masonries with irregular arrangements are typical of historical and archaeological contexts. Several studies involving the characterization through DTs of irregular stone masonry panels reproducing old typologies (particularly diagonal compression tests and axial compression tests) are available in the technical literature [3-5]. Few other studies focused on the definition of proper relationships between the results of DTs and NDTs obtained on the same masonry specimens, particularly focusing on the use of sonic pulse velocity tests (STs) [6-9]. Indeed, ST is considered an effective method for a qualitative structural assessment of existing masonry structures, and few applications of STs on the archaeological structures at the Pompeii site are also available $[10,11]$. However, the available set of data is still limited and robust empirical correlations are still lacking.

This paper presents a wide experimental program aimed at the characterization of rubble stone masonry panels reproducing one of the most common masonry typologies at the archaeological Pompeii site (Italy), the ancient building technique opus incertum. The masonry panels were produced based on a deep survey of the ancient technique and using original rock units and new mortar compliant with the ancient one. This latter was produced with precious volcanic sand coming from the same volcanic region where the ancient builders collected their pulvis puteolanus, i.e. the Phlegrean area, next to the Bay of Naples. The characterization involved extensive sonic pulse velocity tests, three diagonal compression tests carried out in an open space laboratory equipped at the Pompeii site, and five axial compression tests conducted in the laboratory of the University of Naples.

In the following, the experimental program is presented along with the results provided by tests. Moreover, a discussion and comparison of the results obtained from the different NDTs and DTs performed and a comparison with available data from literature is presented.

\section{EXPERIMENTAL PROGRAMME}

Given the impossibility of performing DTs or MDTs on archaeological structures, this experimental program involved the realization and characterization through NDTs and DTs of Pompeii-like rubble stone masonry panels compliant with the ancient building technique opus 
incertum. The panels were built by using original stone units collected within the archaeological excavations started at Regio $V$ in 2018 and mortar compatible with the ancient one, i.e. made with lime putty and pozzolan with a binder to aggregate ratio $1: 3$ by volume. The pozzolan used in the mortar was precious volcanic sand coming from the same volcanic region where the ancient builders collected their pulvis puteolanus, i.e. the Phlegrean area, next to the Bay of Naples. The masonry panels were constructed by experienced masons inside a specifically dedicated test area at Regio $V$ (Figure 1). Indeed, a first part of the experimental program was carried out in the on-site test area, involving: i) realization and storage of the panels; ii) execution of NDTs, i.e. sonic pulse velocity tests (STs) at different ages; iii) execution of DTs, i.e. diagonal compression tests. After that, the final phase of the experimental program was carried out in the laboratory of the University of Naples, involving the execution of axial compression tests on masonry specimens extracted from the undamaged portions of the panels after the diagonal compression tests. In the following, details of the experimental program are reported.

\section{Plan of the archaeological Pompeii site}

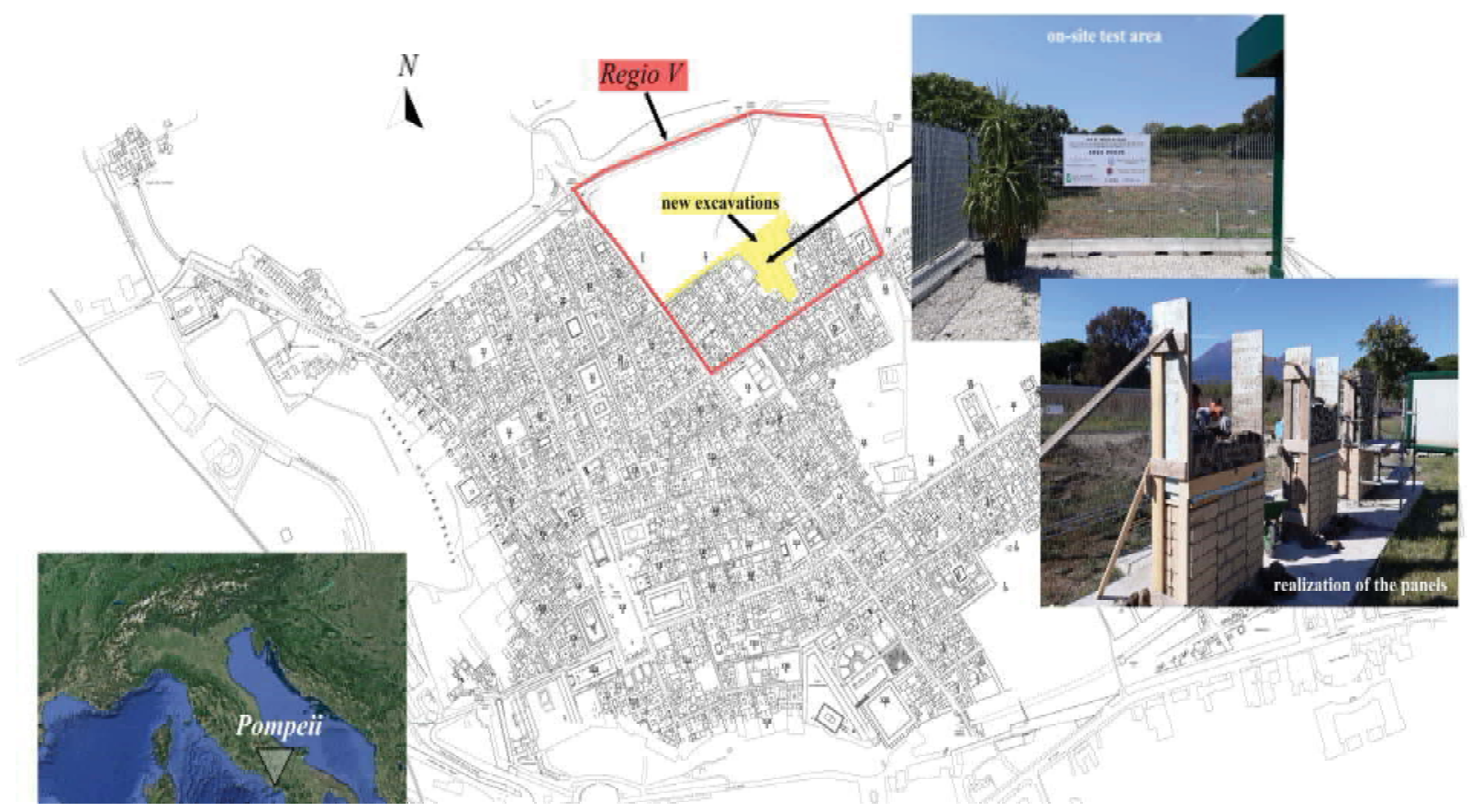

Figure 1: Plan of the archaeological Pompeii site with the indication of the localization of the city of Pompeii in Italy; the borders of the Regio $V$; the area of the new excavations at the Regio $V$; the localization and pictures of the on-site test area.

\subsection{Pompeii-like masonry panels}

For the production of the panels, detailed geometric and material surveys of archaeological opus incertum masonry structures were firstly carried out (Figure 2 (a)), then stone units belonging to collapsed masonry structures found throughout the excavations at Regio $V$ were collected (Figure 2 (b)). According to this preliminary study, the panels were realized with two external leaves made of about $30 \%$ of mortar and $70 \%$ of irregularly shaped units of lava, travertine, and foam lava, with few fragments of other materials. The internal core was made of abundant mortar and stone fragments and smaller units (Figure 2 (c)). The wall thickness was defined as equal to $0.45 \mathrm{~m}$, based on the values detected on similar walls, and no transversal connecting elements between the external leaves were inserted. The panels had a size of $1.20 \mathrm{~m} \times 1.20 \mathrm{~m} \times 0.45 \mathrm{~m}$, according to the standard ASTM E 51902 regarding the execution of diagonal compression tests on masonry wall panels [12]. They were progressively identified as S1, S2, and S3 (Figure 6Figure 2 d) [13]. Mechanical characterization of the stone units and mortar constituting the panels was also performed $[14,15]$. The tests performed 
on the stone units resulted in mean bulk density and compressive strength equal to $2358 \mathrm{~kg} / \mathrm{m}^{3}$ and $38 \mathrm{MPa}, 1380 \mathrm{~kg} / \mathrm{m}^{3}$ and $6 \mathrm{MPa}, 859 \mathrm{~kg} / \mathrm{m}^{3}$ and $4 \mathrm{MPa}$, for the lava, travertine and foam lava, respectively. The tests performed on the mortar specimens resulted in mean bulk density and compressive strength equal to $1105 \mathrm{~kg} / \mathrm{m}^{3}$ and $3 \mathrm{MPa}$, at two months of curing.

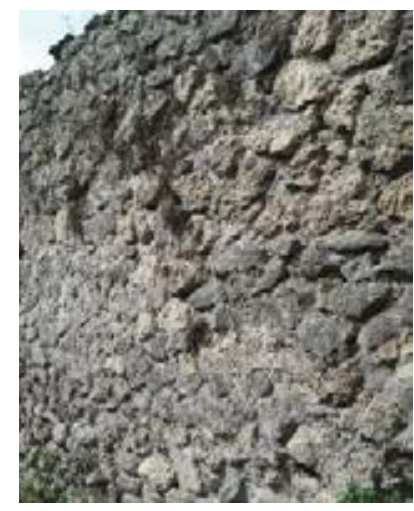

(a)

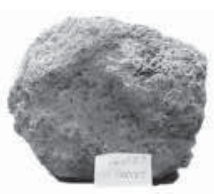

lava unit

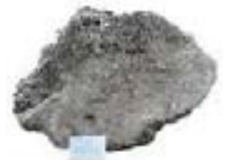

foam lava unit

(b)

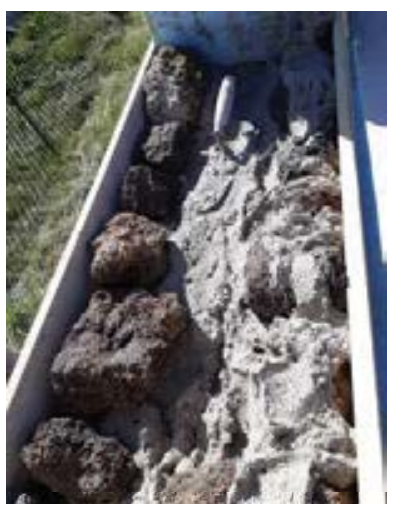

(c)

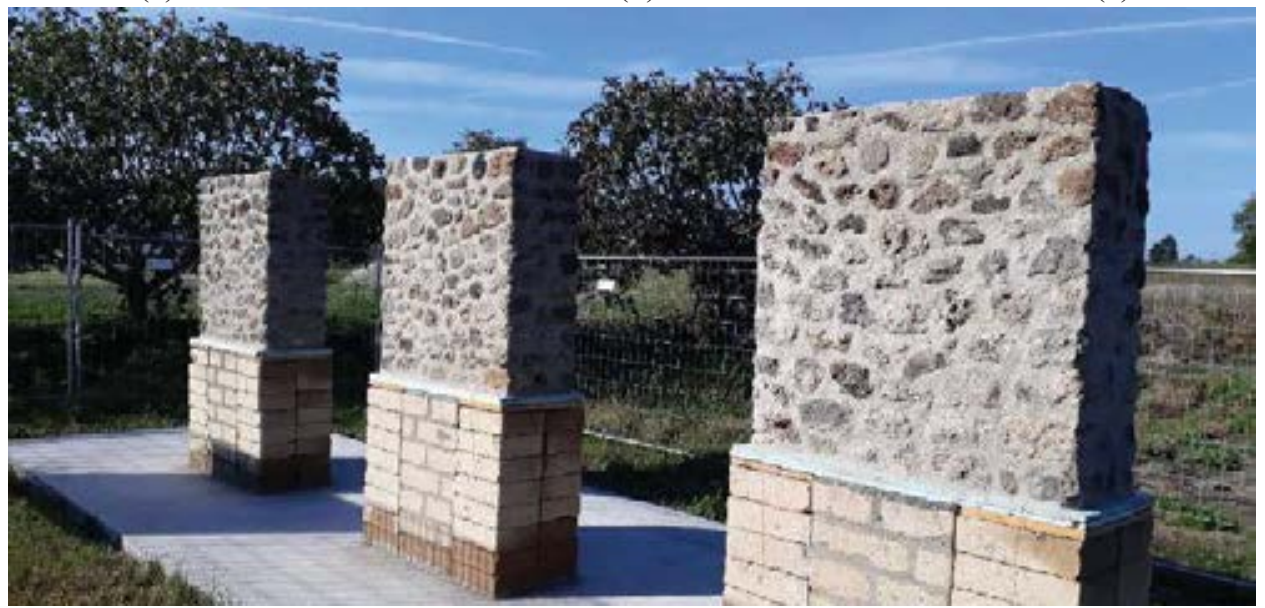

(d)

Figure 2: Pompeii-like masonry panels: view of archaeological opus incertum masonry structure (a); typologies of the stone units used to make the panels (b); cross-section of a panel during the construction phase (c) and view of the completed panels (from the right S1, S2, and S3) (d).

\subsection{Non-destructive testing}

An extensive program of STs was carried out on the new masonry panels to provide useful data for comparison with archaeological opus incertum at the site, to monitor the hardening process in the panels, and to assess the presence of any correlation with results of DTs. The tests were performed by transparency, employing a piezoelectric hammer transducer and a piezoelectric broadband receiver, with $55 \mathrm{KHz}$ resonance frequency and internal pre-amplification of $20 \mathrm{~dB}$, and a coupling material between the receiver and the masonry surface. The tests were carried out at 12, 44 and 148 days from the realization of the panels; a modular mesh, $0.10 \mathrm{~m}$ spaced, with 121 acquisition points was investigated on each panel (Figure 3). For each point, the velocity was calculated from the conventional path length, equal to the thickness of the panel, divided by the mean of three recorded values of travel time. Thus, the mean velocity for each panel at each age was calculated as the mean of the points. 


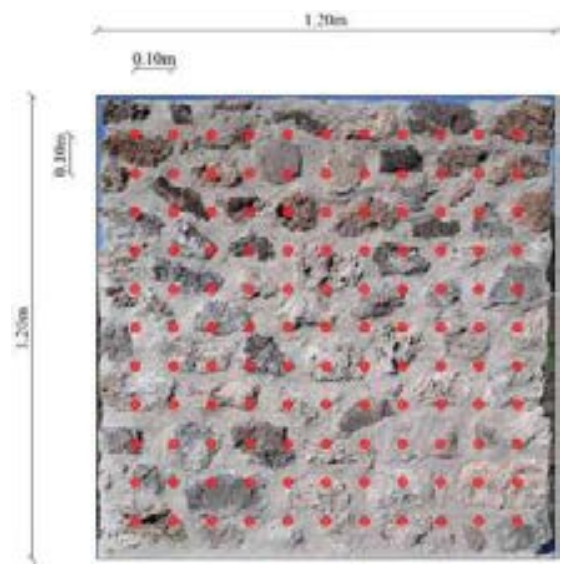

Figure 3: Modular mesh $1.00 \mathrm{~m} \times 1.00 \mathrm{~m}, 0.10 \mathrm{~m}$ spaced, on the masonry panels $\mathrm{S} 1$.

\subsection{Destructive testing}

After the Sts, the experimental program involving DTs started with the in-situ diagonal compression tests (these were carried out after 5 days from the last STs, i.e. 153 days from the production of the panels), to obtain essential information on the shear behavior of the opus incertum masonry and to correlate these results with those provided by DTs. The tests were performed with a specific custom-designed set-up for the outdoor tests. According to the standard ASTM E 519-02 [12], the shear stress, $\tau$, the shear strain, $\gamma$, and the shear modulus of elasticity, $G$, were derived from the tests. In this formulation, a uniform shear stress state is assumed and the tensile strength is equal to the shear capacity, $\tau_{\max }$. The tests were carried out with single loading ramps under displacement control with a rate of $0.02 \mathrm{~mm} / \mathrm{s}$. Devices for the measurement of the in-plane displacements were applied on the two leaves of each panel [13].

Once diagonal tets were completed, five masonry specimens were extracted from the undamaged portion of the panels for the execution of axial compression tests in the laboratory. The masonry specimens were identified as $\mathrm{C} 1, \mathrm{C} 2, \mathrm{C} 3, \mathrm{C} 4$ and $\mathrm{C} 5$. The first test, performed on $\mathrm{C} 1$, was carried out with a single loading ramp to determine the specimen capacity, the following ones involved cyclic testing protocols set between $10 \%$ and $50 \%$ of the maximum load attained in the first test. This to investigate the elastic behavior of the specimen, according to what is suggested in the standard EN 1052-1 [16]. Note that two cycles were performed with C2, then three cycles were performed with $\mathrm{C} 3, \mathrm{C} 4$ and $\mathrm{C} 5$. For each test, the axial compressive strength, $\mathrm{f}_{\mathrm{c}}$, was evaluated as the maximum compressive stress achieved by the panel, $\sigma_{\max }$, i.e. the maximum compression load recorded divided by the area of the loaded cross-section. The elastic modulus, E, was evaluated by making a linear least-squares fit the loading ramp of the cycle in the stress-strain curves and calculating the mean of the slopes of the three obtained lines, as shown in Figure 4.

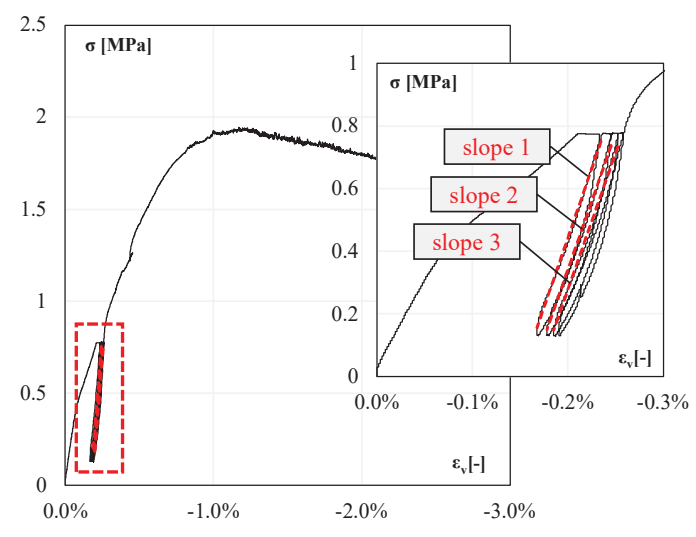

Figure 4: Scheme of determination of the mean elastic modulus of the three loading/unloading cycles of each test. 
Considering the anisotropy of masonry specimens, two different Poisson ratios were also calculated for each specimen: in the horizontal, $v_{\mathrm{h}}(1)$, and transversal, $v_{\mathrm{t}}(2)$, direction.

$$
v_{h}=\frac{\varepsilon_{h}\left(\frac{1}{3}\right)}{\varepsilon_{v}\left(\frac{1}{3}\right)}
$$

$$
v_{t}=\frac{\varepsilon_{t}\left(\frac{1}{3}\right)}{\varepsilon_{v}\left(\frac{1}{3}\right)}
$$

where $\varepsilon_{\mathrm{V}}(1 / 3), \varepsilon_{\mathrm{h}}(1 / 3)$ and $\varepsilon_{\mathrm{t}}(1 / 3)$ are the vertical, horizontal and transversal strain corresponding to one-third of the maximum compressive stress, being each of them calculated as the mean of the values recorded on loading ramps of the loading/unloading cycles.

\section{EXPERIMENTAL RESULTS}

\subsection{Sonic pulse velocity tests}

Figure 5 summarizes the results of the STs for each panel at 12, 44 and 148 days in terms of probability density distributions of the velocities and mean velocities with their coefficients of variation, $\mathrm{CoV}$. The velocities detected on the panels increased with time, consistently with the evolution of the hardening process in the mortar. The mean velocity at 144 days resulted equal to $2428 \mathrm{~m} / \mathrm{s}, 2923 \mathrm{~m} / \mathrm{s}$ and $2767 \mathrm{~m} / \mathrm{s}$, for S1, S2 and S3 respectively.

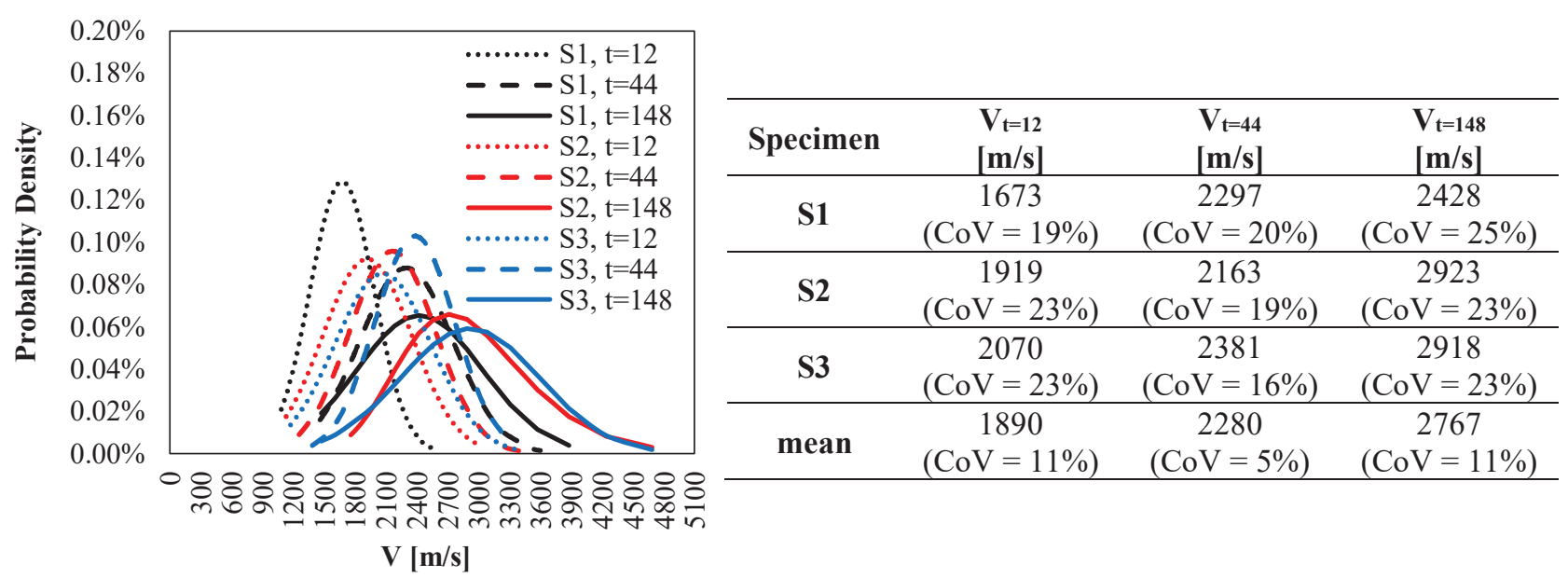

Figure 5: Probability density distributions of the velocities recorded at 12, 44 and 148 days for each panel and summary of the mean velocities with their coefficients of variation.

\subsection{Diagonal compression tests}

Table 1 reports the main outcomes of the diagonal compression tests, in terms of maximum shear stress attained, $\tau_{\max }$, shear strain corresponding to the maximum shear stress, $\gamma_{\tau \max }$, shear strain corresponding to the conventional failure assumed as strength degradation of $20 \%$ of the peak force, $\gamma_{\mathrm{u}}$, and the shear modulus of elasticity, G. This latter was not derived for S3 due to inaccurate local recordings. Different values of the shear capacities were detected, with the maximum stress attained by S2 (i.e. $0.27 \mathrm{MPa}$ ) and the minimum one attained by S1 (i.e. $0.19 \mathrm{MPa}$ ). The values of the shear strain corresponding to the maximum shear stress and of the shear modulus of elasticity were similar among the panels, while a certain variability was again detected in terms of shear strain at the conventional failure. The variability detected in the outcomes was probably related to the different specific arrangements and quantities of the single building materials in each panel. 
Table 1: Main outcomes of the on-site diagonal compression tests.

\begin{tabular}{|c|c|c|c|c|}
\hline Specimen & $\begin{array}{c}\tau_{\max } \\
{[\mathrm{MPa}]}\end{array}$ & $\begin{array}{c}\gamma \tau \max \\
{[\%]}\end{array}$ & $\begin{array}{c}\gamma_{u} \\
{[\%]}\end{array}$ & $\begin{array}{c}\mathbf{G} \\
{[\mathrm{MPa}]}\end{array}$ \\
\hline S1 & 0.19 & 0.16 & 0.90 & 522 \\
\hline S2 & 0.27 & 0.17 & 2.13 & 520 \\
\hline S3 & 0.25 & 0.16 & 1.24 & - \\
\hline mean & $\begin{array}{c}0.23 \\
(\mathrm{CoV}=16 \%)\end{array}$ & $\begin{array}{c}0.16 \\
(\mathrm{CoV}=3 \%)\end{array}$ & $\begin{array}{c}1.42 \\
(\mathrm{CoV}=44 \%)\end{array}$ & 521 \\
\hline
\end{tabular}

The failure mode was consistent among the panels. It resulted in the development of the main crack along the compressed diagonal dividing each panel into two almost symmetric parts. The crack pattern mainly developed in the mortar, but occasionally involved rock units, particularly travertine and foam lava. Indeed, this latter had a lower compressive strength compared to the lava. Figure 6 shows each panel at the end of the diagonal compression test with the indication of the final crack pattern and the masonry specimens extracted from the undamaged portions for the execution of the axial compression tests.

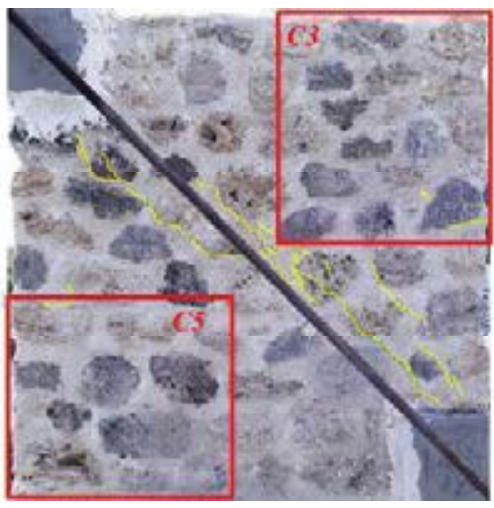

(a)

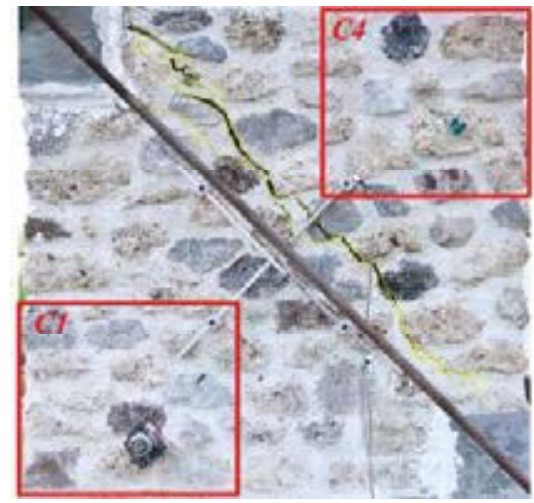

(b)

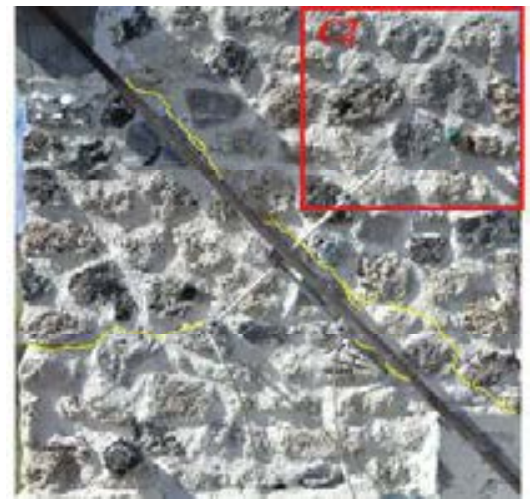

(c)

Figure 6: Crack pattern of the masonry panels S1 (a), S2 (b and S3 (c) with the indication (red boxes) of the masonry specimens extracted for the execution of the axial compression tests.

\subsection{Axial compression tests}

Table 2 reports the main outcomes of the axial compression tests, in terms of maximum compressive stress attained, $\sigma_{\max }$, vertical, horizontal and transversal strain corresponding to the maximum compressive stress, $\varepsilon_{\mathrm{v} \sigma \mathrm{max}}, \varepsilon_{\mathrm{h} \sigma \max }$ and $\varepsilon_{\mathrm{t} \sigma \max }$, vertical strain corresponding to the conventional failure assumed as a strength degradation of $20 \%$ of the peak force, $\varepsilon_{\mathrm{u}}$, modulus of elasticity, E, Poisson ratios in the horizontal, $v_{\mathrm{h}}$, and transversal, $v_{\mathrm{t}}$, directions. Note missing values of $\varepsilon_{\mathrm{u}}$ are related to the fact that the conventional failure was not achieved and missing values of $v_{\mathrm{h}}$ and $v_{\mathrm{t}}$ are related to inaccurate local recordings. The outcomes of the axial compression tests are also summarized in Figure 7, which plots the compressive stress-vertical strain relationships for C1, C2, C3, C4 and C5. Specimen C4 showed the highest values of compressive stress and corresponding vertical strain, while $\mathrm{C} 3$ showed the lowest ones. $\mathrm{C} 3$ also showed the lowest elastic modulus, while the highest value was showed by $\mathrm{C} 2$. The highest variability of the results was detected for the Poisson ratios. However, the overall dispersion of these results has been considered acceptable considering the proper inhomogeneity of the masonry typology and consistent with what was found from the sonic tests and diagonal compression tests. 
Table 2: Main outcomes of the axial compression tests.

\begin{tabular}{|c|c|c|c|c|c|c|}
\hline Specimen & $\begin{array}{c}\sigma \max \\
{[\mathrm{MPa}]}\end{array}$ & $\begin{array}{c}\text { Evomax } \\
{[\%]}\end{array}$ & $\begin{array}{c}\mathcal{E} u \\
{[\%]}\end{array}$ & $\begin{array}{c}\mathbf{E} \\
{[\mathrm{MPa}]}\end{array}$ & $\begin{array}{l}\text { vh } \\
{[-]}\end{array}$ & $\begin{array}{l}v_{t} \\
{[-]}\end{array}$ \\
\hline C1 & 1.52 & 0.59 & - & - & 0.08 & - \\
\hline $\mathrm{C2}$ & 1.49 & 0.52 & - & 1253 & 0.24 & 0.03 \\
\hline C3 & 0.96 & 0.40 & - & 843 & - & - \\
\hline C4 & 1.95 & 1.17 & 2.77 & 1053 & 0.07 & 0.08 \\
\hline $\mathrm{C5}$ & 1.46 & 0.89 & 2.37 & 862 & - & - \\
\hline mean & $\begin{array}{c}1.48 \\
(\mathrm{CoV}=24 \%)\end{array}$ & $\begin{array}{c}0.71 \\
(\mathrm{CoV}=44 \%)\end{array}$ & $\begin{array}{c}2.57 \\
(\mathrm{CoV}=11 \%) \\
\end{array}$ & $\begin{array}{c}1003 \\
(\mathrm{CoV}=19 \%)\end{array}$ & $\begin{array}{c}0.13 \\
(\mathrm{CoV}=75 \%)\end{array}$ & $\begin{array}{c}0.05 \\
(\mathrm{CoV}=66 \%)\end{array}$ \\
\hline
\end{tabular}

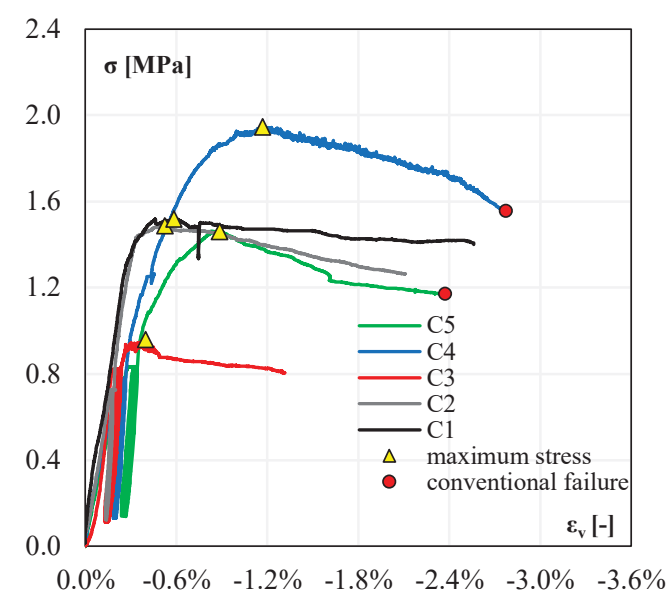

Figure 7. Compressive stress-vertical strain curves.

Figure 8 shows the specimens at failure. For all the specimens, the first cracks were vertical and thin and involved the mortar matrix, finally, the expulsion of material outward occurred and several stone units were also damaged. The units involved in the cracks were travertine and foam lava, consistently with what was found in the diagonal compression tests. In many cases, the first cracks developed in the central part of the cross-section of the specimens. However, clear detachments of the external leaves from the internal core were not detected on the final crack pattern but cracks distributed over the entire cross-section of the wall. Indeed, due to the irregular arrangement of the masonry assemblage along with its thickness, the separation between the core and the leaves was not sharply defined.

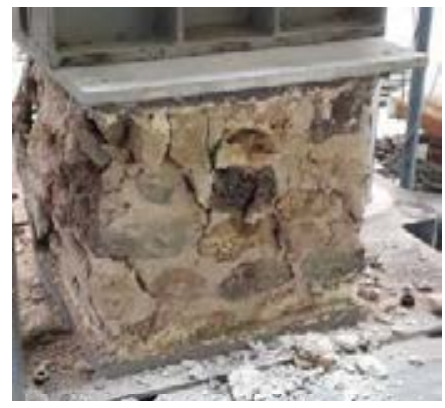

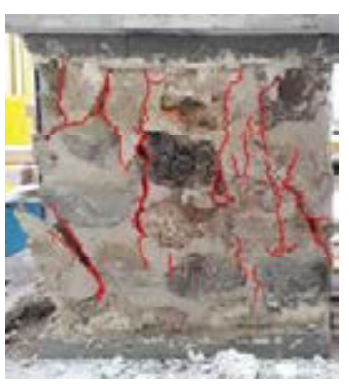

(a)

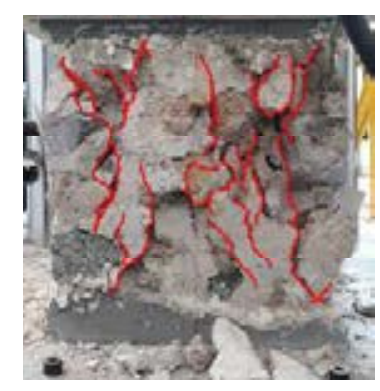



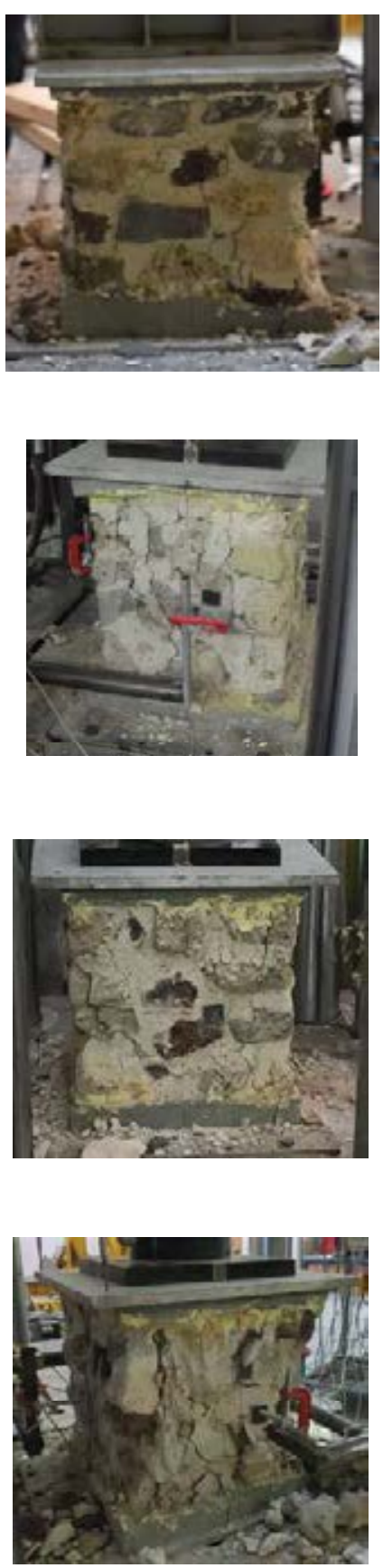

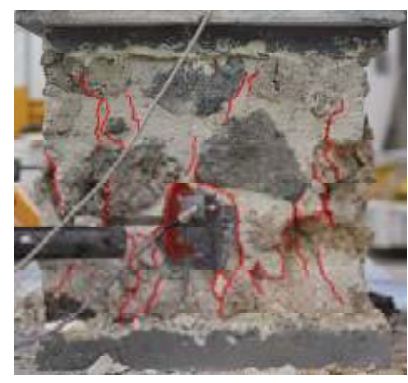

(b)

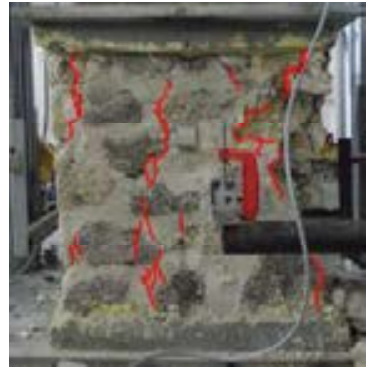

(c)

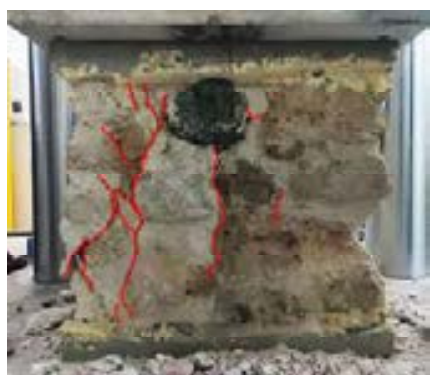

(d)

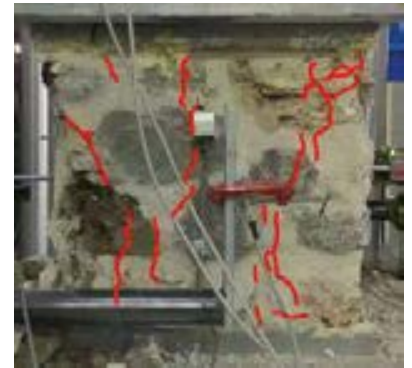

(e)
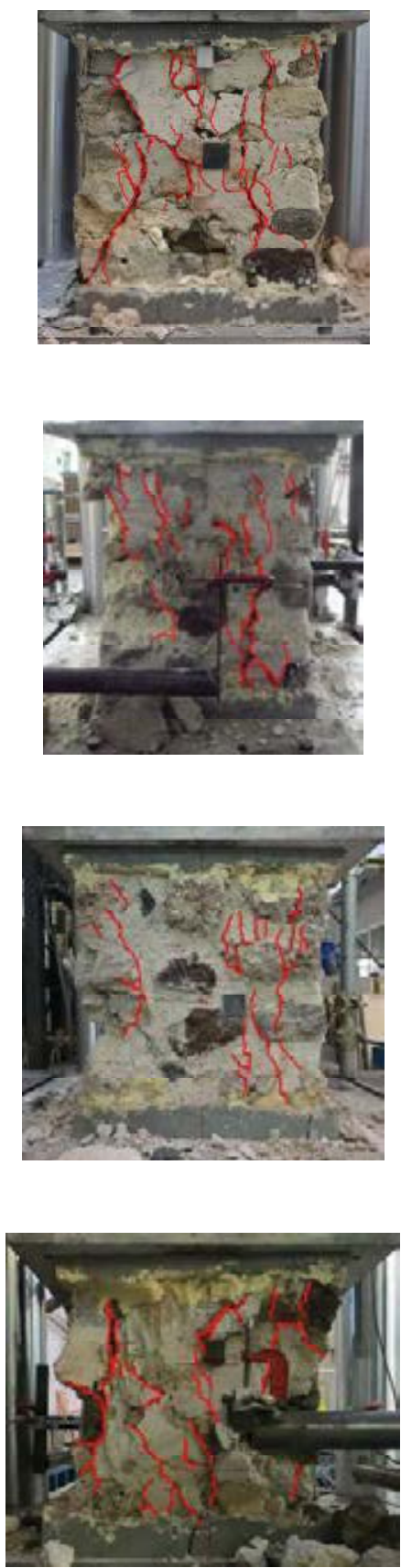

Figure 8. Specimens crack pattern on two orthogonal sides of the panel C1 (a), C2 (b), C3 (c), C4 (d) and C5 (e).

\section{DISCUSSION OF THE RESULTS AND COMPARISONS}

Table 3 summarizes the main results of the mechanical characterization through NDTs and DTs of the Pompeii-like masonry panels.

Table 3. Main experimental outcomes of sonic pulse velocity tests, diagonal compression tests and axial compression tests.

\begin{tabular}{|c|c|c|c|c|c|c|c|c|}
\hline \multirow{3}{*}{$\begin{array}{c}3 \text { masonry panels } \\
1.20 \mathrm{~m} \times 1.20 \mathrm{~m} \times 0.45 \mathrm{~m}\end{array}$} & $\begin{array}{c}\mathbf{V} \\
{[\mathbf{m} / \mathbf{s}]}\end{array}$ & $\begin{array}{c}\tau_{\max } \\
{[\mathrm{MPa}]}\end{array}$ & $\begin{array}{c}\mathbf{G} \\
{[\mathrm{MPa}]} \\
\end{array}$ & \multirow{3}{*}{$\begin{array}{c}5 \text { masonry specimens } \\
0.45 \mathrm{~m} \times 0.45 \mathrm{~m} \times 0.45 \mathrm{~m} \\
\text { (average sizes) }\end{array}$} & $\begin{array}{c}\sigma_{\max } \\
{[\mathrm{MPa}]} \\
\end{array}$ & $\begin{array}{c}\mathbf{E} \\
{[\mathrm{MPa}]}\end{array}$ & $\begin{array}{l}v_{h} \\
{[-]}\end{array}$ & $\begin{array}{l}v_{t} \\
{[-]}\end{array}$ \\
\hline & 2767 & 0.23 & 521 & & 1.48 & 1003 & 0.13 & 0.05 \\
\hline & $11 \%$ & $16 \%$ & - & & $24 \%$ & $19 \%$ & $75 \%$ & - \\
\hline
\end{tabular}


The final mean velocity achieved by the panels ( $\mathrm{V}=2767 \mathrm{~m} / \mathrm{s}, \mathrm{CoV}=11 \%)$ can be associated with good-quality stone masonry, according to a common classification found in the literature [17] (Table 4). This result is consistent with what was found in similar experimentations on stone masonry panels reproducing historical typologies, with good compactness $[18,19]$. Instead, lower values of velocity were found for historical or archaeological masonry structures $[6,10,11]$ or reproduced panels incorporating flaws or inclusions [20]. Indeed, the sonic pulse velocity is greatly affected by differences in the building materials and inner and superficial conditions of the structure.

Table 4. Relations between the masonry overall conditions and the mean sonic pulse velocity value.

\begin{tabular}{cccc}
\hline & Poor-quality masonry & Medium-quality masonry & Good-quality masonry \\
\hline Range of velocities $[17]$ & $<1500 \mathrm{~m} / \mathrm{s}$ & $1500 \mathrm{~m} / \mathrm{s}-2500 \mathrm{~m} / \mathrm{s}$ & $2500 \mathrm{~m} / \mathrm{s}<$ \\
\hline
\end{tabular}

Table 5 reports a literature review of the main results obtained from diagonal compression tests and axial compression tests on stone masonry panels reproducing traditional typologies. Despite the general scatter, the obtained results are comparable with the available data from the literature. In particular, the obtained shear strength is comparable with the experiments by Milosevic et al., Gattesco et al. and Magenes et al., and lower value of the shear modulus compared to Gattesco et al. and Magenes et al. was probably related to a lower amount of mortar and more regular textures in the specimens investigated in these latter [3-5]. Moreover, as regards the compressive strength and modulus of elasticity lower values found in this study compared to available literature data were probably related to relatively low capacity, deterioration and pre-existing damage of several of the archaeological stone units used in this work.

Table 5. Literature review of experimental outcomes of diagonal compression tests and axial compression tests on reproduced stone masonry panels.

\begin{tabular}{|c|c|c|c|c|c|c|c|}
\hline Source & Masonry type & $\begin{array}{c}\tau \text { mean, } \\
\text { ASTM } \\
{[\mathrm{MPa}]}\end{array}$ & $\begin{array}{l}\text { G mean, } \\
\text { ASTM } \\
{[\mathrm{MPa}]}\end{array}$ & $\begin{array}{c}\boldsymbol{\sigma}_{\max } \\
{[\mathrm{MPa}]}\end{array}$ & $\begin{array}{c}\mathbf{E} \\
{[\mathrm{MPa}]}\end{array}$ & $\begin{array}{l}v_{h} \\
{[-]}\end{array}$ & $\begin{array}{l}v_{t} \\
{[-]}\end{array}$ \\
\hline $\begin{array}{l}\text { Milosevic et } \\
\text { al. } 2013\end{array}$ & $\begin{array}{c}\text { Rubble stone masonry, made with } \\
\text { hydraulic lime-based mortar and limestone } \\
\text { units }\end{array}$ & 0.29 & 321 & 8.01 & 1640 & - & - \\
\hline $\begin{array}{l}\text { Gattesco et } \\
\text { al. } 2015^{*}\end{array}$ & $\begin{array}{l}\text { Rubble stone masonry, made with two } \\
\text { types of lime-based mortar }\end{array}$ & 0.19 & 1051 & - & - & - & - \\
\hline $\begin{array}{l}\text { Magenes et } \\
\text { al. } 2010\end{array}$ & $\begin{array}{c}\text { Reproduced rubble stone masonry, made } \\
\text { with hydraulic lime based mortar and } \\
\text { calcareous sandstone units }\end{array}$ & 0.20 & 840 & 3.28 & 2550 & 0.19 & 0.15 \\
\hline \multirow[t]{2}{*}{$\begin{array}{l}\text { Valluzzi } \\
2000\end{array}$} & $\begin{array}{c}\text { Rubble stone masonry, made with a lime- } \\
\text { based mortar and rough-shaped limestone } \\
\text { blocks bonded in sub-horizontal courses } \\
\text { (original panels) }\end{array}$ & - & - & 1.82 & 1858 & - & - \\
\hline & (injected panels) & - & - & 2.46 & 2347 & - & - \\
\hline \multirow[t]{2}{*}{ Silva 2012} & $\begin{array}{l}\text { Rubble stone masonry, made with a } \\
\text { hydraulic lime-based mortar and rough- } \\
\text { shaped limestone blocks bonded in sub- } \\
\text { horizontal courses (original panels) }\end{array}$ & - & - & $\begin{array}{l}2.1- \\
2.9\end{array}$ & $\begin{array}{l}1837- \\
2335\end{array}$ & $\begin{array}{c}0.01- \\
0.67\end{array}$ & $\begin{array}{c}0.03- \\
0.12\end{array}$ \\
\hline & (injected panels) & - & - & $\begin{array}{c}3.7- \\
5.4\end{array}$ & $\begin{array}{c}2565- \\
5205\end{array}$ & $\begin{array}{c}0.003- \\
0.09\end{array}$ & $\begin{array}{c}0.02- \\
0.87\end{array}$ \\
\hline
\end{tabular}

Despite the number of data collected in this investigation is not enough to define reliable correlations, a preliminary correlation between STs and DTs results can be formulated using the obtained experimental results. Indeed, the results of the last STs were in good agreement with the results of the diagonal compression tests, with the maximum shear stress achieved being higher for 
the panels which showed the higher mean sonic velocity (i.e. $V=2923 \mathrm{~m} / \mathrm{s}$ and $\tau_{\max }=0.27$ for $\mathrm{S} 2$, $\mathrm{V}=2918 \mathrm{~m} / \mathrm{s}$ and $\tau_{\max }=0.25$ for $\mathrm{S} 3$, and $\mathrm{V}=2428 \mathrm{~m} / \mathrm{s}$ and $\tau_{\max }=0.19$ for $\mathrm{S} 1$ ) (Figure 9 ).

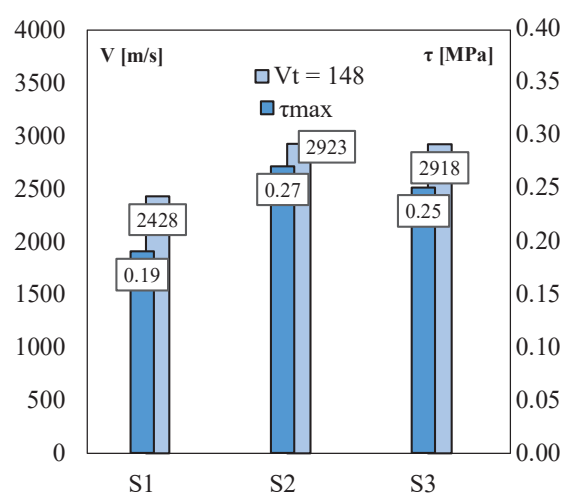

Figure 9: Values of the mean sonic pulse velocity at 148 days and maximum shear stress achieved by the masonry panels $1.20 \mathrm{~m} \times 1.20 \mathrm{~m} \times 0.45 \mathrm{~m}$ with diagonal compression tests.

On the contrary, the results obtained from STs in terms of modulus of elasticity of the masonry did not comply with the one obtained from the DTs. Indeed, from the well-known formula defined for homogeneous materials and also applied to concrete [21] (3):

$$
E_{d}=V^{2} \frac{\rho(1-2 v)(1+v)}{(1-v)}
$$

with $\mathrm{V}$ equal to the mean sonic velocity of the specimen at 148 days, $v$ equal to the mean horizontal Poisson ratio resulting from the axial compression tests and $\rho$ equal to the bulk density of the masonry calculated with a simplified homogenization procedure from the bulk density of the single building materials (i.e. equal to $1406 \mathrm{~kg} / \mathrm{m}^{3}$ ), the resulting dynamic modulus of elasticity, $\mathrm{E}_{\mathrm{d}}$, is equal to 10058 $\mathrm{MPa}$, i.e. ten times higher than the mean value obtained from the axial compression tests. This result shows that eq. (3) is not reliable to predict the elastic modulus of rubble masonry.

\section{CONCLUSIONS}

This paper presents the results of a wide experimental program aimed at the mechanical characterization of masonry panels reproducing the ancient technique opus incertum found at the Pompeii archaeological site. Non-destructive tests (NDTs) and destructive tests (DTs) were carried out on masonry panels built according to the traditional technique by using original rock units and a typical mortar mixture. The experimental program firstly involved sonic pulse velocity tests and diagonal compression tests on three masonry panels, $1.20 \mathrm{~m} \times 1.20 \mathrm{~m} \times 0.45 \mathrm{~m}$. Then, axial compression tests on five masonry specimens extracted from the three panels were carried out.

The following main conclusions may be drawn:

- The panels showed a mean sonic pulse velocity at 148 days after their construction equal to $2767, \mathrm{CoV}=11 \%$;

- The on-site diagonal compression test resulted in a mean shear strength equal to $0.23 \mathrm{MPa}$, $\mathrm{CoV}=16 \%$, and a mean shear modulus of elasticity equal to $521 \mathrm{MPa}$. These results are comparable with what found in similar experiments on other typologies of reproduced stone masonry structures;

- The axial compression tests resulted in a mean compressive strength of $1.48 \mathrm{MPa}, \mathrm{CoV}=$ $24 \%$, and mean modulus of elasticity equal to $1003 \mathrm{MPa}, \mathrm{CoV}=0.19 \%$; 
- The Poisson ratios in the horizontal and transversal direction derived from the axial compression tests resulted equal to $0.13, \mathrm{CoV}=75 \%$, and 0.05 , respectively. High scattering of these values was also found in other studies;

- The final mean velocity resulting from the sonic tests was consistent with the results of the diagonal compression tests, with the higher velocities showed by the panels that also achieved the maximum shear strength;

- The mean dynamic elastic modulus calculated from the sonic pulse velocity was found to be ten times higher than the one obtained from the axial compression tests.

The information here provided could support the assessment of several archaeological masonry structures in the exceptional context of the Pompeii site and similar archaeological and historical contexts.

\section{ACKNOWLEDGMENTS}

The authors acknowledge the former director of Parco Archeologico di Pompei (PAP), Prof. Massimo Osanna; the Lead Project Manager of the new works in Regio V, Arch. Annamaria Mauro; the Managers of the Laboratorio di Ricerche Applicate of PAP, Archt. Bruno De Nigris and Dr. Alberta Martellone; the Director of works in Regio V, Archt. Gianluca Vitagliano; the member of the Technical Secretariat of the Great Pompeii Project Eng. Vincenzo Calvanese and the research center STRESS S.c.a.r.l. for the support provided to this research.

\section{REFERENCES}

[1] ICOMOS, Recommendations for the analysis, conservation and structural restoration of architectural heritage, (2003) 1-37. https://ancientgeorgia.files.wordpress.com/2012/04/recommendations_icomos-principlesand-guidelines.pdf.

[2] Italian Ministry of Cultural Heritage and Activities, Linee guida per la valutazione e la riduzione del rischio sismico del patrimonio culturale con riferimento alle Norme tecniche per le costruzioni di cui al decreto del Ministero delle Infrastrutture e dei trasporti del 14 gennaio 2008, (2010).

[3] G. Magenes, A. Penna, A. Galasco, M. Rota, Experimental characterisation of stone masonry mechanical properties, 8th Int. Mason. Conf. 2010. (2010) 1-10.

[4] N. Gattesco, I. Boem, A. Dudine, Diagonal compression tests on masonry walls strengthened with a GFRP mesh reinforced mortar coating, Bull. Earthq. Eng. 13 (2015) 1703-1726.

[5] J. Milosevic, A.S. Gago, M. Lopes, R. Bento, Experimental assessment of shear strength parameters on rubble stone masonry specimens, Constr. Build. Mater. 47 (2013) 1372-1380. https://doi.org/10.1016/j.conbuildmat.2013.06.036.

[6] G. Riva, C. Bettio, C. Modena, The use of sonic wave technique for estimating the efficiency of masonry consolidation by injection, IB2MAC - 11h Int. Brick Block Mason. Conf. Shanghai, China. (1997) 28-39.

[7] B. Silva, M. Dalla Benetta, F. Da Porto, M.R. Valluzzi, Compression and sonic tests to assess effectiveness of grout injection on three-leaf stone masonry walls, Int. J. Archit. Herit. 8 (2014) 408-435. https://doi.org/10.1080/15583058.2013.826300.

[8] M. Berra, A. Fatticcioni, Non destructlve evaluation of the efficacy of masonry strengthening by grouting techniques, (1992) 1457-1464.

[9] L.F. Miranda, J. Rio, J. Miranda Guedes, A. Costa, Sonic Impact Method - A new technique for characterization of stone masonry walls, Constr. Build. Mater. 36 (2012) 27-35. https://doi.org/10.1016/j.conbuildmat.2012.04.018.

[10] H. Dessales, Villa de Diomède. Campagne d'étude 2015, Chronique des activités archéologiques de l'École française de Rome, 2015. http://cefr.revues.org/1293.

[11] M.R. Valluzzi, F. Lorenzoni, R. Deiana, S. Taffarel, C. Modena, Non-destructive 
investigations for structural qualification of the Sarno Baths, Pompeii, J. Cult. Herit. 40 (2019) 280-287. https://doi.org/10.1016/j.culher.2019.04.015.

[12] ASTM, E 519-02. Standard Test Method for Diagonal Tension (Shear) in Masonry Assemblages, Am. Soc. Test. Mater. (2002) 5. https://doi.org/10.1520/E0519.

[13] F. Autiero, G. De Martino, M. Di Ludovico, A. Prota, Mechanical performance of full-scale Pompeii-like masonry panels, Constr. Build. Mater. $251 \quad$ (2020) 118964. https://doi.org/10.1016/j.conbuildmat.2020.118964.

[14] F. Autiero, G. De Martino, M. Di Ludovico, A. Prota, Mechanical properties of rock units from the Pompeii archaeological site, Italy, in: P. De Wilde (Ed.), Struct. Stud. Repairs Maint. Herit. Archit. XVI, 2019: pp. 341-350. https://doi.org/10.2495/STR190291.

[15] F. Autiero, G. De Martino, M. Di Ludovico, A. Prota, Mechanical behavior of ancient mortar specimens from Pompeii site, in: Proc. 7th Int. Conf. Comput. Methods Struct. Dyn. Earthq. Eng. (COMPDYN 2015), Institute of Structural Analysis and Antiseismic Research School of Civil Engineering National Technical University of Athens (NTUA) Greece, Athens, 2019: pp. 1251-1262. https://doi.org/10.7712/120119.6994.18836.

[16] CEN, EN 1052-1. Methods of test for masonry - Part 1: Determination of compressive strength, Eur. Comm. Stand. (1999) 10969.

[17] M.C. Forde, K.F. Birjandi, A.J. Batchelor, Fault detection in stone masonry bridges by nondestructive testing, in: Proc. 2nd Int. Conf. Struct. Faults Repair, Engineering Technics Press, Edinburgh, 1985: pp. 373-379.

[18] B.L. Silva, Diagnosis and Strengthening of Historical Masonry Structures: Numerical and Experimental Analysis, 2012.

[19] M.R. Valluzzi, Comportamento meccanico delle murature consolidate con materiali e tecniche a base di calce, Università degli studi di Trieste, 2000.

[20] M.R. Valluzzi, E. Cescatti, G. Cardani, L. Cantini, L. Zanzi, C. Colla, F. Casarin, Calibration of sonic pulse velocity tests for detection of variable conditions in masonry walls, Constr. Build. Mater. 192 (2018) 272-286. https://doi.org/10.1016/j.conbuildmat.2018.10.073.

[21] ASTM, C 597 - 02. Pulse Velocity Through Concrete, United States Am. Soc. Test. Mater. 04 (2003) 3-6. https://doi.org/10.1520/C0597-09. 